\title{
Synthesis of a New Compound $\mathrm{NaGaTi}_{5} \mathrm{O}_{12}$
}

\author{
新物質 $\mathrm{NaGaTi}_{5} \mathrm{O}_{12}$ の合成 \\ 藤木良規・道上勇一・渡辺 遵 \\ 無機材質研究所, 305 つくば市並木 1-11
}

Yoshinori FUJIKI, Yuichi MICHIUE and Mamoru WATANABE

National Institute for Research in Inorganic Materials, 1-1, Namiki, Tsukuba-shi, Ibaraki

305

[Received September 17, 1990; Accepted December 14, 1990]

\begin{abstract}
Single crystals of a new compound $\mathrm{NaGaTi}_{5} \mathrm{O}_{12}$ were synthesized by the flux method. This crystal always occurred in coexistence with $\mathrm{Na}_{1-x} \mathrm{Ti}_{x} \mathrm{Ga}_{5-x} \mathrm{O}_{8}$ crystals. The best crystal was obtained by slow-cooling after keeping at $1350^{\circ} \mathrm{C}$ for $10 \mathrm{~h}$ using a mixture of $35 \mathrm{~mol} \%$ crystal composition of $\left(\mathrm{Mo}_{2} \mathrm{O}\right)_{1}\left(\mathrm{Ga}_{2} \mathrm{O}_{3}\right)_{1}\left(\mathrm{TiO}_{2}\right)_{1}$ and 65 mol\% flux composition of $\left(\mathrm{Na}_{2} \mathrm{O}\right)_{1}\left(\mathrm{MoO}_{3}\right)_{1.5}$ as a compositional condition in the flux melt. This crystal structure consists of peculiar framework with one-dimensional tunnel structure of a new type which is a monoclinic system with $a=15.202(\AA), b=3.732(\AA)$, $c=9.317(\AA)$ and $\beta=122.04^{\circ}$. This compound was identified as a high temperature phase of $\mathrm{Na}-\mathrm{Ga}$-freudenbergite $\left(\mathrm{Na}_{0.7} \mathrm{Ga}_{0.7} \mathrm{Ti}_{3.3} \mathrm{O}_{8}\right)$ which transformed at $1238^{\circ} \mathrm{C}$, and melted at $1336^{\circ} \mathrm{C}$.
\end{abstract}

Key-words: New tunnel structure, Sodium gallotitanate, $\mathrm{NaGaTi}{ }_{5} \mathrm{O}_{12}$, Flux growth

\section{Introduction}

A new compound $\mathrm{NaGaTi}{ }_{5} \mathrm{O}_{12}$ (hereafter NGTO) was synthesized by the flux method. This crystal structure was coincident with that predicted as a possible structure in alkali-metal titanates by Andersson and Wadsley $^{1)}$ and the hypothetical substance has been given to have a composition $\mathrm{A}_{2} \mathrm{Ti}_{6} \mathrm{O}_{12}(\mathrm{~A}=$ alkali-metals).

We succeeded in synthesizing the NGTO crystals by replacing $\mathrm{Ti}$ sites in the $\mathrm{Na}_{2} \mathrm{Ti}_{6} \mathrm{O}_{12}$ with $\mathrm{Ga}$. In this paper, the growth conditions, chemical composition, structure and thermal stability of single crystals are described.

\section{Experimental}

Starting materials were $\mathrm{TiO}_{2}, \mathrm{Ga}_{2} \mathrm{O}_{3}$ and $\mathrm{MoO}_{3}$ powders of $99.99 \%$ purity and $\mathrm{Na}_{2} \mathrm{CO}_{3}$ powder of 99.9\%. The flux employed was a mixture of $\mathrm{Na}_{2} \mathrm{CO}_{3}$ and $\mathrm{MoO}_{3}$ powders. A $100 \mathrm{ml}$ Pt-crucible which was tightly covered with fitted lid was used in this work. The growth crystals were taken out from the crucible by dissolving the flux in hot water. The chemical compositions of single crystals were determined by the EPMA method.

\section{Results and discussion}

\subsection{Single crystal synthesis}

Table 1 exhibits the compositional conditions in the flux melts and the obtained results for the single crystal growth of NGTO. In the compositional conditions of the flux melts shown in Table 1, the crystal composition is the composition of the mixture of crystal components and the flux composition is that of the mixture of flux components using as the solvent. The NGTO single crystals were synthesized by slowcooling after keeping at $1350^{\circ} \mathrm{C}$ for $10 \mathrm{~h}$ using a mixture of a crystal composition of $\left(\mathrm{Na}_{2} \mathrm{O}\right)_{1}\left(\mathrm{Ga}_{2} \mathrm{O}_{3}\right)_{1}$ $\left(\mathrm{TiO}_{2}\right)_{1}$ in $30-35 \mathrm{~mol} \%$ and a flux composition of $\left(\mathrm{Na}_{2} \mathrm{O}\right)_{1}\left(\mathrm{MoO}_{3}\right)_{1.5}$ in $65-70 \mathrm{~mol} \%$. The slow cooling operation was carried out to $1000^{\circ} \mathrm{C}$ with a rate of $4^{\circ} \mathrm{C} / \mathrm{h}$. The weight loss of the bulk composition dur-

Table 1. The compositional conditions in flux melts and the obtained results for the growth of $\mathrm{NaGaTi}_{5} \mathrm{O}_{12}$ single crystals by the flux method.

\begin{tabular}{|c|c|c|c|c|c|c|c|}
\hline \multirow{2}{*}{$\begin{array}{l}\text { Temperature } \\
\text { High } \longrightarrow \text { Low } \\
\left({ }^{\circ} \mathrm{C}\right)\end{array}$} & \multicolumn{3}{|c|}{$\begin{array}{l}\text { Crystal composition (C) } \\
\left(\mathrm{Na}_{2} \mathrm{O}\right)-\left(\mathrm{Ga}_{2} \mathrm{O}_{3}\right)-\left(\mathrm{TiO}_{2}\right) \\
\text { (Molar ratio) }\end{array}$} & \multicolumn{2}{|c|}{$\begin{array}{l}\text { Flux comp. }(\mathrm{F}) \\
\left(\mathrm{Na}_{2} \mathrm{O}\right)-\left(\mathrm{MoO}_{3}\right) \\
\text { (Molar ratio) }\end{array}$} & \multirow{2}{*}{$\begin{array}{c}\text { Melt cmpo. } \\
\text { C/F } \\
(\text { Mol\%) }\end{array}$} & \multirow{2}{*}{$\frac{\text { Crystals }^{*}}{\mathrm{TiO}_{2}, \mathrm{NTGO}}$} \\
\hline & 0.5 & 0.5 & 5.0 & 1.0 & 1.5 & & \\
\hline $1350 \longrightarrow 1000$ & 0.5 & 0.5 & 3.5 & 1.0 & 1.5 & $20 / 80$ & $\mathrm{TiO}_{2}$, NTGO \\
\hline $1350 \longrightarrow 1000$ & 0.75 & 0.5 & 1.5 & 1.0 & 1.5 & $20 / 80$ & $\mathrm{TiO}_{2}, \mathrm{NTGO}$ \\
\hline $1300 \longrightarrow 1000$ & 1.0 & 1.0 & 1.0 & 1.0 & 1.5 & $30 / 70$ & NTGO, NGTO, $\left(\mathrm{TiO}_{2}\right)$ \\
\hline $1350 \longrightarrow 1000$ & 1.0 & 1.0 & 1.0 & 1.0 & 1.5 & $35 / 65$ & NTGO, NGTO \\
\hline $1350 \longrightarrow 1000$ & 2.0 & 1.0 & 1.0 & 1.0 & 1.5 & $30 / 70$ & NTGO, $\mathrm{Na}_{2} \mathrm{Ti}_{3} \mathrm{O}_{7}$ \\
\hline $1350 \longrightarrow 1000$ & 1.0 & 1.0 & 1.0 & 1.0 & 1.25 & $30 / 70$ & NTGO, $\mathrm{Na}_{2} \mathrm{Ti}_{3} \mathrm{O}_{7}$ \\
\hline
\end{tabular}

* NGTO $=\mathrm{NaGaTi}_{5} \mathrm{O}_{12}, \mathrm{NTGO}=\mathrm{Na}_{1-\mathrm{x}} \mathrm{Ti}_{\mathrm{x}} \mathrm{Ga}_{5-\mathrm{x}} \mathrm{O}_{8}, \mathrm{TiO}_{2}=$ rutile, $($ )=small amount 
ing a growth process was below $1 \mathrm{wt} \%$. However, the NGTO crystals always occurred in coexistance with $\mathrm{Na}_{1-x} \mathrm{Ti}_{x} \mathrm{Ga}_{5-x} \mathrm{O}_{8}$ crystals. ${ }^{2)}$ The NGTO crystals could not be synthesized when the crystal composition in a flux melt was stoichiometrical with that of NGTO, and rutile and $\mathrm{Na}_{1-x} \mathrm{Ti}_{x} \mathrm{Ga}_{5-x} \mathrm{O}_{8}$ crystals were always prepared. Especially, rutile was very predominant with a acicular form. The NGTO crystals were synthesized under some conditions which $\mathrm{Na}_{1-x} \mathrm{Ti}_{x} \mathrm{Ga}_{5-x} \mathrm{O}_{8}$ crystals occurred prodominantly instead of rutile. Consequently, the monophase of NGTO crystals is not yet obtained. Figure 1 shows the NGTO single crystals grown by the flux method. Those crystals are obtained in an acicular form elongating along the $c$-axis (or the tunnel axis) with transparence or translucence. Figure 2 shows crystal structure projected on the (010) plane of NGTO, and the crystallographical properties are exhibited in Table 2. The crystal structure is characterized by a new type of tunnel framework consisting of treble
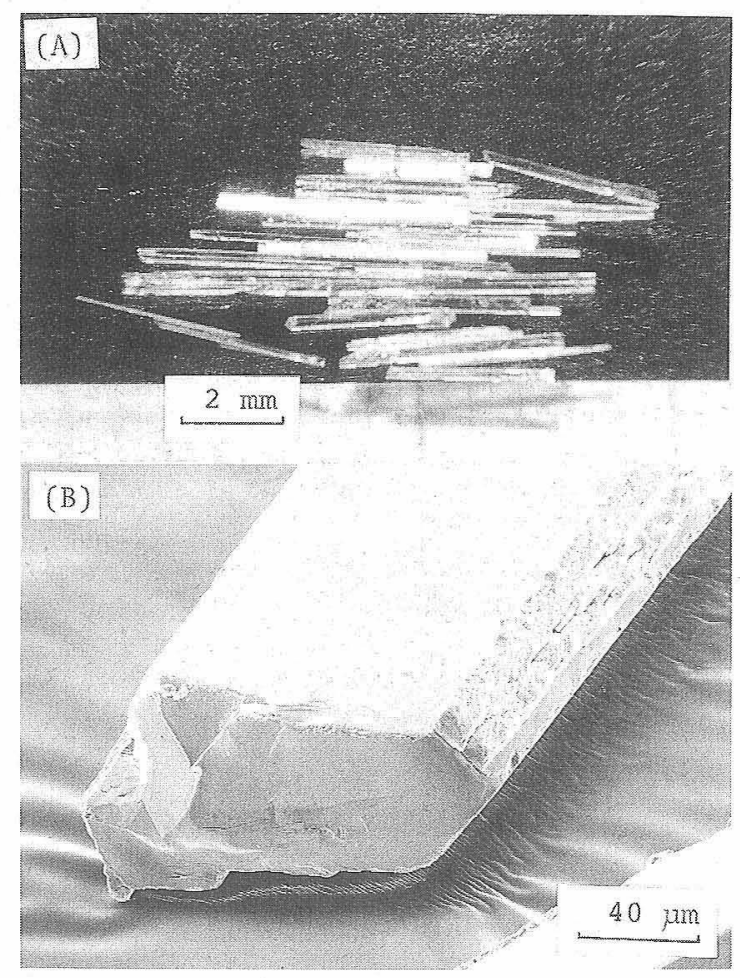

Fig. 1. $\mathrm{NaGaTi}_{5} \mathrm{O}_{12}$ single crystals grown by the flux method; (A) Stereoscopic photomicrograph, (B) SEM image.
(Ga, Ti) $\mathrm{O}_{6}$ octahedral ribbon. This tunnel framework and the crystallographical properties resemble that of sodium hexatitanate $\mathrm{Na}_{2} \mathrm{Ti}_{6} \mathrm{O}_{13}$ which has been reported by Andersson and Wadsley ${ }^{1)}$ except for the $\beta$ angle is different. An only $\mathrm{Na}$ ion is able to occupy in a unit tunnel. The detail of structure analysis is to be published by Michive et al. ${ }^{3)}$ Table 3 shows the chemical compositions of NGTO crystals analyzed by the EPMA method. The formula was calculated on the basis of atomic ratio as $\mathrm{O}_{12}$ in a chemical composition. As the results, the general formula indicated to be $\mathrm{NaGaTi}_{5} \mathrm{O}_{12}$ as a stoichiometrical composition.

\subsection{Polycrystal synthesis}

The NGTO polycrystal was also prepared by the solid reactions. It was found that the polycrystal was synthesized at temperatures of $1250^{\circ} \mathrm{C}$ or above. At temperatures of $1200^{\circ} \mathrm{C}$ or below, only $\mathrm{Na}-\mathrm{Ga}$ freudenbergite, $\mathrm{Na}_{0.7} \mathrm{Ga}_{0.7} \mathrm{Ti}_{3.3} \mathrm{O}_{8}$, was always synthesized using the same starting composition. The ob-

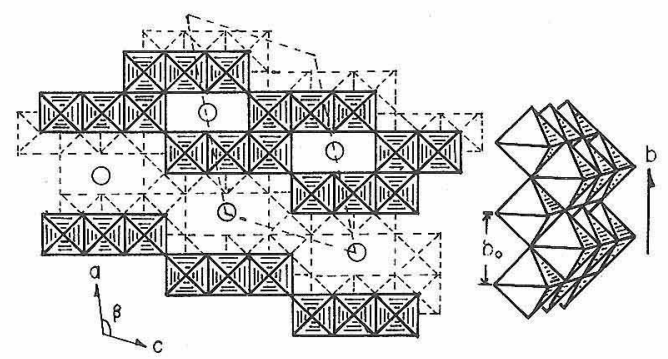

Fig. 2. The crystal structure projected on the (010) plane of $\mathrm{NaGaTi}_{5} \mathrm{O}_{12}$ crystal.

Table 2. The crystallographical properties of $\mathrm{NaGaTi}_{5} \mathrm{O}_{12}$ comparing with that of $\mathrm{K}_{2} \mathrm{Ti}_{6} \mathrm{O}_{13}$.

\begin{tabular}{|c|c|}
\hline $\begin{array}{c}\mathrm{NaGaTi}_{5} \mathrm{O}_{12} \\
\text { (NGTO) }\end{array}$ & $\begin{array}{c}\mathrm{K}_{2} \mathrm{Ti}_{6} \mathrm{O}_{13} \\
\text { (КTO) }\end{array}$ \\
\hline Monoclinic, $(\mathrm{C} 2 / \mathrm{m})$ & Monoclinic, $(\mathrm{C} 2 / \mathrm{m})$ \\
\hline$a(\AA)=15.202$ & 15.131 \\
\hline $\mathrm{b}(\AA)=3.732$ & 3.745 \\
\hline$c(\AA)=9.317$ & 9.159 \\
\hline$B^{\circ}=122.04$ & 99.3 \\
\hline$V\left(\AA^{3}\right)=448.1$ & 512.1 \\
\hline $\mathrm{D}\left(\mathrm{g} \cdot \mathrm{cm}^{-3}\right)=3.88$ & 3.51 \\
\hline$z=\quad 2$ & 2 \\
\hline
\end{tabular}

Table 3. The chemical cmpositions of $\mathrm{NaGaTi}_{5} \mathrm{O}_{12}$ single crystals analyzed by the EPMA methoc

\begin{tabular}{cccccc}
\hline No. & $\left(\mathrm{Na}_{2} \mathrm{O}\right)$ & $\begin{array}{c}\left(\mathrm{Ga}_{2} \mathrm{O}_{3}\right) \\
(\mathrm{wt} \%)\end{array}$ & $\left(\mathrm{TiO}_{2}\right)$ & Total & Chemical compositions \\
\hline 1 & 6.245 & 17.522 & 77.751 & 105.518 & $\mathrm{Na}_{1.04} \mathrm{Ga}_{0.96^{\mathrm{Ti}}} 5.01^{\mathrm{O}} 12.00$ \\
& $(6.152)$ & $(17.260)$ & $(76.588)$ & $(100.000)$ & \\
2 & 6.396 & 17.182 & 77.328 & 100.898 & $\mathrm{Na}_{1.07} \mathrm{Ga}_{0.95^{\mathrm{Ti}}} 5.02^{\mathrm{O}}{ }_{12.00}$ \\
& $(6.339)$ & $(17.029)$ & $(76.640)$ & $(100.000)$ & \\
3 & 6.328 & 19.147 & 76.403 & 101.870 & $\mathrm{Na}_{1.05^{\mathrm{Ga}}} \mathrm{O}_{1.05^{\mathrm{Ti}}}{ }_{4.94} \mathrm{O}_{12.00}$ \\
& $(6.211)$ & $(18.795)$ & $(75.00)$ & $(100.000)$ & \\
\hline
\end{tabular}


tained Na-Ga-freudenbergite transformed into a NGTO phase by reheating at $1250^{\circ} \mathrm{C}$. Figure 3 shows a DTA curve of Na-Ga-freudenbergite which was prepared at $1200^{\circ} \mathrm{C}$ for $25 \mathrm{~h}$ with a stoichiometrical $\mathrm{NaGaTi}_{5} \mathrm{O}_{12}$ composition. It indicates that the freudenbergite transforms irreversibly to an NGTO

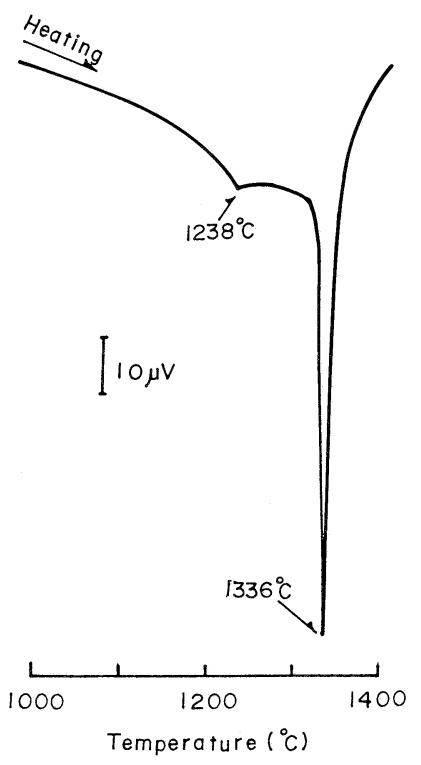

Fig. 3. A DTA curve of Na-Ga-freudenbergite polycrystal prepared at $1200^{\circ} \mathrm{C}$ for $25 \mathrm{~h}$ with a $\mathrm{NaGaTi}_{5} \mathrm{O}_{12}$ composition. phase at $1238^{\circ} \mathrm{C}$ and melt at $1336^{\circ} \mathrm{C}$. This phase transformation is represented by no change of composition as follows;

$$
1.5 \mathrm{Na}_{0.7} \mathrm{Ga}_{0.7} \mathrm{Ti}_{3.3} \mathrm{O}_{8} \stackrel{1238^{\circ} \mathrm{C}}{\longrightarrow} \mathrm{NaGaTi}_{5} \mathrm{O}_{12}
$$

We also tried to synthesize $\mathrm{KGaTi}_{5} \mathrm{O}_{12}$ and $\mathrm{LiGaTi}_{5} \mathrm{O}_{12}$ compounds which replaced $\mathrm{Na}$ ion in the NGTO with $\mathrm{K}$ or $\mathrm{Li}$ ions at $1250^{\circ} \mathrm{C}$ for $25 \mathrm{~h}$. As the results, it was unsuccessful, and rutile and priderite, $\mathrm{K}_{2} \mathrm{Ga}_{2} \mathrm{Ti}_{6} \mathrm{O}_{16}$, were obtained in the former, and in the latter, rutile and $\mathrm{LiGaTiO}_{4}{ }^{4)}$ Furthermore, we tried to prepare a $\mathrm{NaAlTi}_{5} \mathrm{O}_{12}$ compound as the analogue of NGTO at $1200^{\circ}$ and $1250^{\circ} \mathrm{C}$ for $20 \mathrm{~h}$. However, only Na-Al-freudenbergite, $\mathrm{Na}_{0.7} \mathrm{Al}_{0.7} \mathrm{Ti}_{3.3} \mathrm{O}_{8}$, was obtained. This freudenbergite decomposed into freudenbergite (perhaps $\mathrm{Na}_{0.7-x} \mathrm{Al}_{0.7-x} \mathrm{Ti}_{3.3+} \mathrm{O}_{\delta}$ ) and $\mathrm{Na}-\beta^{\prime \prime}-\mathrm{Al}_{2} \mathrm{O}_{3}$ phases at $1350^{\circ} \mathrm{C}$ for $20 \mathrm{~h}$.

Acknowledgement The authors thank Mr. Kosoda in NIRIM for his kindness of the EPMA analysis of the single crystals.

\section{References}

1) S. Andersson and A. D. Wadsley, Acta Cryst., 15, 149-201 (1962).

2) G. V. Chandrashekhar, B. Bednowitz and S. J. Laplaca, "Fast Ion Transport in Solids", Eds. P. Vashista, J. N. Mundy and G. K. Shenoy, Elsevier North Holland Inc. (1979) pp. 44750.

3) Y. Michiue, Y. Fujiki and M. Watanabe, to be published in Acta Cryst.

4) E. F. Bertaut and G. Patrat, Bull. Soc. Franc. Miner. Cryst., 88, 586-89 (1965) 